\title{
Long term health implications of fitness and physical activity patterns
}

\author{
C Riddoch, J M Savage, N Murphy, G W Cran, C Boreham
}

\begin{abstract}
Northern Ireland has the highest incidence of coronary heart disease (CHD) in the world. The physical fitness, activity patterns, health knowledge, attitudes, and dietary habits of a random, stratified sample of 3211 Northern Irish children, comprising 1540 boys and 1671 girls, age range 11-18 years were examined. At all ages boys were significantly more active than girls. The most important finding was an appreciable decline in physical activity levels after the age of 14 years reaching extremely low levels in older girls. While $75 \%$ of exercise taken was not related to school, physical education classes constituted the only exercise taken by one third of pupils. Girls had healthier nutritional habits and were more inclined to employ weight control measures than boys. There was a preponderance of children with a higher body mass index indicating a tendency to obesity in the child population. Over $20 \%$ of school leavers of both sexes regularly smoked cigarettes and $20 \%$ regularly drank alcohol. The postulated relationship between childhood inactivity, adult sedentary lifestyle, and increased risk of CHD raises serious cause for concern regarding the future cardiovascular health of many children.
\end{abstract}

An unhealthy diet, cigarette smoking, and lack of exercise are implicated in the development of coronary heart disease (CHD). ${ }^{1}$ It is a matter of great concern that today's children may be acquiring such habits and therefore a future risk of $\mathrm{CHD}$ at least as great as that of the present generation of adults. Northern Ireland has had the highest incidence of CHD in the world ${ }^{2}$ and the purpose of this paper is to report the findings of a recent survey of the fitness and lifestyles of Northern Ireland children. In the latter part of this century there has been a dramatic reduction in the amount of physical activity performed in daily life because of the use of motorised transport and a plethora of labour saving devices. It is now possible for the great majority of both children and adults to get through every day of their lives with a minimal amount of physical activity.

It is firmly established that lack of sufficient and appropriate exercise is a major risk factor for CHD. In a thorough examination of the literature Powell et al reviewed 43 of the most rigorous epidemiological studies and concluded that an inverse relationship between physical activity and CHD could be identified in over two thirds of the studies, ${ }^{3}$ and this postulate has received support from more recent work. ${ }^{45}$
Although studies have not demonstrated a cause and effect relationship between lack of exercise and CHD, it has been consistently shown that adults who are more physically active have a lower risk of cardiovascular disease than those who are not. ${ }^{6-9}$

Data from a number of studies suggest that risk factors for cardiovascular disease can be identified in children and that most of the risk factors track into adult life. ${ }^{10-13}$ The Bogalusa heart study, the most extensive study of risk factors for CHD beginning in early life, has shown that the extent of aortic fatty streaks is strongly related to serum cholesterol concentrations in the young. ${ }^{14}$ Physical activity has been shown to improve the lipid profile and this, together with other possible mechanisms, has the potential to protect against heart disease. ${ }^{15}$ Encouraging physical activity and the pursuit of fitness in children may therefore have significant health benefits.

The Northern Ireland Health and Fitness Survey (NIHFS) was a national survey commissioned to investigate the activity levels, physical fitness, attitudes, dietary habits, and health knowledge of Northern Irish schoolchildren.

\section{Subjects and sampling}

All secondary schools in Northern Ireland $(n=256)$ were grouped according to pupil sex, perceived religion, and selection category (grammar or secondary modern/comprehensive). Each school was given a weighting according to pupil numbers and a random selection of 20 schools was chosen to provide the widest range of pupils in each age/sex group. In each school the age of all children on the school roll was calculated for that school's test week and a random selection of children from each age group was made. The variability of each fitness test was assessed during a pilot study and from examination of the width of the $95 \%$ confidence intervals for the median, a target sample size of 200 for each age/sex group was considered adequate for the purposes of the study. A total of 3211 children ( $1 \cdot 25 \%$ of the age population) was tested. Based on pilot study experience all strata were oversampled by $20 \%$ to allow for non-consent or absence from school (table 1). As most children of 17 and 18 years do not attend school, results from these age groups cannot be considered as necessarily representative of the whole population.

\section{METHODS}

Written consent was obtained from the parents of all children participating in the study and the 
Table 1 Numbers of children tested and response rates

\begin{tabular}{|c|c|c|c|c|c|c|}
\hline \multirow{2}{*}{$\begin{array}{l}\text { Age } \\
\text { (years) }\end{array}$} & \multicolumn{4}{|c|}{ Children tested } & \multicolumn{2}{|c|}{ Response rate $(\%)^{*}$} \\
\hline & $\begin{array}{l}\text { No of } \\
\text { boys }\end{array}$ & $\begin{array}{l}\text { Mean } \\
\text { age }\end{array}$ & $\begin{array}{l}\text { No of } \\
\text { girls }\end{array}$ & $\begin{array}{l}\text { Mean } \\
\text { age }\end{array}$ & Boys & Girls \\
\hline $\begin{array}{l}11 \\
12 \\
13 \\
14 \\
15 \\
16 \\
17 \\
18 \\
\text { All } \\
\text { Total No samples }\end{array}$ & $\begin{array}{r}223 \\
209 \\
211 \\
207 \\
215 \\
209 \\
181 \\
85 \\
1504\end{array}$ & $\begin{array}{l}11 \cdot 7 \\
12 \cdot 5 \\
13 \cdot 5 \\
14 \cdot 4 \\
15 \cdot 5 \\
16 \cdot 4 \\
17 \cdot 5 \\
18 \cdot 3 \\
3211\end{array}$ & $\begin{array}{r}222 \\
233 \\
225 \\
223 \\
221 \\
226 \\
202 \\
119 \\
1671\end{array}$ & $\begin{array}{l}11 \cdot 7 \\
12 \cdot 5 \\
13 \cdot 5 \\
14 \cdot 3 \\
15 \cdot 5 \\
16 \cdot 4 \\
27 \cdot 5 \\
18 \cdot 3\end{array}$ & $\begin{array}{l}87 \\
85 \\
89 \\
74 \\
63 \\
62 \\
67 \\
64 \\
72\end{array}$ & $\begin{array}{l}85 \\
89 \\
83 \\
80 \\
70 \\
67 \\
67 \\
63 \\
75\end{array}$ \\
\hline
\end{tabular}

*Response rates were calculated using the formula:

No of children tested $\times 100$

Children who were originally sampled, but who could not be contacted or had left school, have been omitted from the calculation. protocols of all tests were approved by the medical ethical committee of the Queen's University of Belfast. All parents completed a medical questionnaire to determine their children's suitability for fitness testing.

\section{LIFESTYLE QUESTIONNAIRE}

This questionnaire collected data on physical activity, diet and nutrition, health knowledge and beliefs, leisure activities, exercise enjoyment and participation, alcohol and tobacco use, and family influences on behaviour.

An administrator supervised the questionnaire completion and gave assistance when appropriate. Strict confidentiality was maintained and this was emphasised to the children.

\section{ANTHROPOMETRY AND FITNESS}

Tests were selected from the Eurofit test battery and, with one exception (endurance run), all tests were carried out according to the protocols of the Eurofit handbook. ${ }^{16}$ Height, weight, skinfold measurements, and the endurance run were performed in the mornings, and tests of flexibility, leg power, trunk strength/endurance, handgrip strength, and running speed/agility tests were performed during the afternoons. The nine tests were administered in the above order throughout the survey. Each test was administered, and results recorded, by the same tester with the exception of the test for handgrip strength, which was administered by the school liaison teacher, after suitable training by the test team.

Height was measured using a Holtain portable stadiometer and weight using Weylux portable beam scales. Skinfold thicknesses were measured using Harpenden fat calipers at mid-bicep, midtricep, subscapular, and suprailiac sites on the right hand side of the body.

Endurance running ability was measured using a progressive, 20 metre shuttle run test, adapted specifically for use with children by the physical education department at the Queen's University of Belfast. ${ }^{17}$ The test requires children to run 20 metre laps in time with a prerecorded audio signal. Running speed increases as the test progresses and the child drops out, or is withdrawn, when he/she can no longer maintain the required pace.
Flexibility was measured using a sit and reach test, which measures combined shoulder, trunk, and hamstring flexibility. Leg power was measured using a standing broad jump test using a wooden take off board with a landing mat graded in centimetres. Abdominal strength/ endurance was measured as the number of sit ups the child could perform in 30 seconds. Sit ups were performed with hands clasped behind the head, the knees bent, and the feet securely held by a partner. Handgrip strength was measured using a grip dynamometer. The dynamometer was held by the side of the thigh while in a standing position and squeezed as hard as possible for 2 or 3 seconds. Running speed was measured using a $10 \times 5$ metre shuttle run. Children were required to sprint between two lines placed 5 metres apart, within a 1.3 metre wide track. The time taken to sprint 10 laps was recorded.

\section{PHYSICAL ACTIVITY}

Three methods of assessing children's activity patterns were used. Firstly, children were asked a series of questions about their habitual physical activity (travel to school, school based activities, out of school activities, etc). Answers were coded according to frequency, intensity, and duration, appropriately weighted and an 'activity score' was computed. Secondly, children were asked to indicate which of four descriptions, relating to lifestyles incorporating differing levels of habitual physical activity, fitted them best. Thirdly, children were asked to complete a seven day recall of physical activity, again based on the frequency, intensity, and duration of exercise.

Each method used two descriptions of intensity: that which causes slight breathlessness and that which causes considerable breathlessness. The aim was to achieve a measure of the children's involvement in light to moderate activity and vigorous activity respectively. For both the activity score and the seven day recall children were 'cued' using a time based framework using the structure of a typical school day. This method was felt to be more accurate than cueing by activities, which is the more traditional method.

It should be stressed that such methods cannot accurately quantify physical activity and therefore we can only refer to 'reported involvement' in physical activity, which is likely to be an overestimate. However, the strength of such methods is that they can be used with large numbers of children and can identify similarities and differences in activity levels at different ages and between the sexes.

In addition to reporting the quantity of physical activity, children were also asked questions about their attitudes to sport, physical activity, and physical education. This included questions about whether they enjoyed physical activity, why they did or did not enjoy it, and the role of physical activity in leisure activities.

\section{TEST ADMINISTRATION}

All tests were carried out by one test team using 
one set of equipment and each test was administered at approximately the same time of day. All equipment was regularly calibrated throughout the duration of the test period.

\section{Results}

\section{RESPONSE RATES}

Response rates by age and sex group are given in table 1 . The target sample size of 200 could not be achieved in children aged 17 and 18 years. Information for these age groups should therefore be interpreted with care.

\section{PHYSICAL ACTIVITY}

Eighty nine per cent of boys and $84 \%$ of girls reported enjoying physical activity of an intensity that caused breathlessness. The commonest reason given in younger children was 'because it's fun' while in older children 'health and fitness' became the most important reason. Two thirds of children who disliked physical activity gave 'discomfort' as the main cause. Seventy nine per cent of boys and $66 \%$ of girls indicated an intention to continue playing sport when they left school.

Only $39 \%$ of boys and $19 \%$ of girls walked to school, whereas $49 \%$ of boys and $29 \%$ of girls walked home from school. Less than $1 \%$ of children cycled regularly to and from school. Less than half the children exercised more than three times per week, but $75 \%$ of the children took exercise on at least one evening per week. There was an obvious decline in physical activity with age, most noticeable in older girls (figure). Boys and girls of 17 and 18 years were approximately $50 \%$ less active than those aged 11-14 years. While $75 \%$ of the activity reported was not related to school, physical education classes were the only source of activity recorded by one third of children.

\section{LIFESTYLE AND LEISURE}

Playing sport was reported as the favourable leisure activity of $47 \%$ boys and $23 \%$ of girls. An appreciable decline was observed in the older

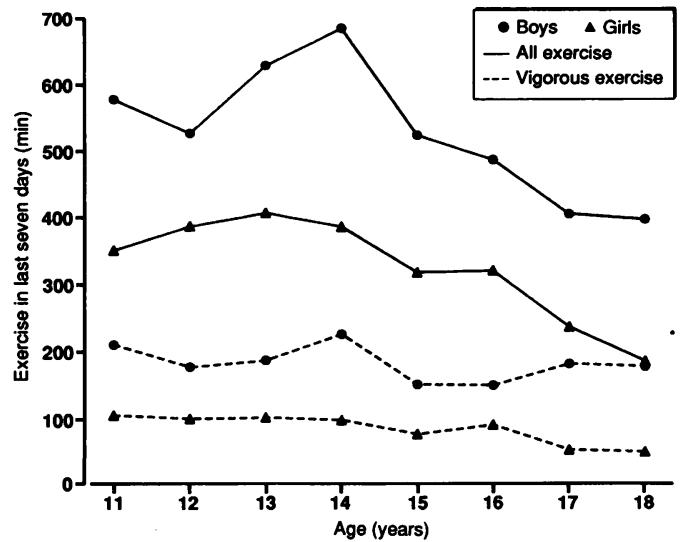

Weekly time (min) spent taking exercise by boys and girls at ages 11 to 18 years.

children with only $20 \%$ of those aged 18 years reporting sport as a favourite activity falling to as low as $9 \%$ of older girls (table 2). 'Chatting with friends' was the most popular activity for older girls $(42 \%)$ and was the most popular pastime for girls overall (23\%). Watching television (15\%) and reading (13\%) were also highly rated. Thirty per cent of boys and $23 \%$ of girls reported having regular jobs, most commonly as shop assistants, working on average 9-10 hours per week. Girls generally spent more time on homework: $66 \%$ spent over one hour per night compared with $46 \%$ of boys. Two thirds of children went to bed before $11 \mathrm{pm}$ on evenings before school days two thirds stayed up later than $11 \mathrm{pm}$ at weekends.

\section{ALCOHOL AND SMOKING}

Fourteen per cent of boys and $11 \%$ of girls reported smoking regularly, the incidence increasing most noticeably between the ages of 12 and 15 years so that by 18 years $20 \%$ of boys and $28 \%$ of girls were regular smokers (table 3 ). Consumption of alcohol increased around the age of 14 years when $13 \%$ of boys and $4 \%$ of girls reported drinking alcohol on at least one occasion per week, rising to $25 \%$ of boys and $11 \%$ of girls at 15 years of age (table 4 ).

Table 2 Children's favourite leisure activities by age (years). Results are percent of children indicating favourite activity

\begin{tabular}{|c|c|c|c|c|c|c|c|c|}
\hline & 11 & 12 & 13 & 14 & 15 & 16 & 17 & 18 \\
\hline $\begin{array}{l}\text { No of boys } \\
\text { No response } \\
\text { Watching TV or video } \\
\text { Playing computer games } \\
\text { Reading for pleasure } \\
\text { Chatting with friends } \\
\text { Playing sport } \\
\text { Doing a job (for money) } \\
\text { Helping with jobs in the house } \\
\text { Doing homework } \\
\text { Other }\end{array}$ & $\begin{array}{r}223 \\
22 \cdot 9 \\
12 \cdot 6 \\
6 \cdot 7 \\
1 \cdot 3 \\
2 \cdot 7 \\
44 \cdot 8 \\
4 \cdot 5 \\
0 \\
0 \\
4 \cdot 5\end{array}$ & $\begin{array}{r}209 \\
13.9 \\
11 \cdot 0 \\
12.9 \\
3.3 \\
2.4 \\
46.4 \\
5.3 \\
0.5 \\
0.5 \\
3.8\end{array}$ & $\begin{array}{r}211 \\
11 \cdot 8 \\
15 \cdot 6 \\
7 \cdot 1 \\
2 \cdot 4 \\
3 \cdot 8 \\
42 \cdot 7 \\
7 \cdot 6 \\
0 \\
0 \\
9 \cdot 0\end{array}$ & $\begin{array}{r}207 \\
13 \cdot 0 \\
12 \cdot 1 \\
6 \cdot 8 \\
1 \cdot 4 \\
2 \cdot 4 \\
45 \cdot 8 \\
7 \cdot 7 \\
1 \cdot 4 \\
0 \\
9 \cdot 7\end{array}$ & $\begin{array}{r}215 \\
10 \cdot 7 \\
11 \cdot 2 \\
5 \cdot 2 \\
0 \cdot 9 \\
8 \cdot 8 \\
38 \cdot 1 \\
12 \cdot 6 \\
1 \cdot 4 \\
0 \cdot 5 \\
10 \cdot 7\end{array}$ & $\begin{array}{r}209 \\
8 \cdot 1 \\
14 \cdot 8 \\
3 \cdot 3 \\
1 \cdot 9 \\
13 \cdot 4 \\
34 \cdot 4 \\
10 \cdot 5 \\
1 \cdot 0 \\
0 \cdot 5 \\
12 \cdot 0\end{array}$ & $\begin{array}{r}181 \\
1 \cdot 1 \\
14 \cdot 9 \\
1 \cdot 7 \\
5 \cdot 0 \\
12 \cdot 2 \\
39 \cdot 8 \\
10 \cdot 5 \\
0 \cdot 6 \\
1 \cdot 1 \\
13 \cdot 3\end{array}$ & $\begin{array}{r}85 \\
5 \cdot 9 \\
14 \cdot 1 \\
2 \cdot 4 \\
1 \cdot 2 \\
24 \cdot 7 \\
31 \cdot 8 \\
1 \cdot 2 \\
0 \\
1 \cdot 2 \\
17 \cdot 6\end{array}$ \\
\hline $\begin{array}{l}\text { No of girls } \\
\text { No response } \\
\text { Watching TV or video } \\
\text { Playing computer games } \\
\text { Reading for pleasure } \\
\text { Chatting with friends } \\
\text { Playing sport } \\
\text { Doing a job (for money) } \\
\text { Helping with jobs in the house } \\
\text { Doing homework } \\
\text { Other }\end{array}$ & $\begin{array}{r}222 \\
18 \cdot 0 \\
19 \cdot 4 \\
3 \cdot 2 \\
9 \cdot 0 \\
10 \cdot 4 \\
25 \cdot 2 \\
1 \cdot 8 \\
3 \cdot 2 \\
0 \cdot 9 \\
9 \cdot 0\end{array}$ & $\begin{array}{r}233 \\
6 \cdot 0 \\
21 \cdot 0 \\
6 \cdot 4 \\
8 \cdot 6 \\
11 \cdot 2 \\
35 \cdot 6 \\
0 \cdot 4 \\
2 \cdot 1 \\
1 \cdot 7 \\
6.9\end{array}$ & $\begin{array}{r}225 \\
10 \cdot 7 \\
21 \cdot 8 \\
4 \cdot 0 \\
6 \cdot 7 \\
15 \cdot 1 \\
27 \cdot 1 \\
2 \cdot 2 \\
2 \cdot 2 \\
2 \cdot 7 \\
7 \cdot 6\end{array}$ & $\begin{array}{r}223 \\
10 \cdot 3 \\
20 \cdot 6 \\
1 \cdot 8 \\
6 \cdot 3 \\
16 \cdot 6 \\
22 \cdot 4 \\
4 \cdot 0 \\
2 \cdot 2 \\
0 \cdot 4 \\
15 \cdot 2\end{array}$ & $\begin{array}{r}221 \\
3 \cdot 6 \\
17 \cdot 2 \\
0 \cdot 5 \\
8 \cdot 1 \\
24 \cdot 9 \\
19 \cdot 9 \\
9 \cdot 0 \\
0 \cdot 5 \\
1 \cdot 4 \\
14 \cdot 9\end{array}$ & $\begin{array}{r}226 \\
3 \cdot 5 \\
14 \cdot 6 \\
0 \\
7 \cdot 1 \\
37 \cdot 2 \\
16 \cdot 4 \\
7 \cdot 5 \\
0 \cdot 9 \\
0 \cdot 4 \\
12 \cdot 4\end{array}$ & $\begin{array}{r}202 \\
2 \cdot 0 \\
9 \cdot 9 \\
0 \cdot 5 \\
9 \cdot 9 \\
37 \cdot 1 \\
17 \cdot 8 \\
3 \cdot 0 \\
0 \\
1 \cdot 0 \\
18 \cdot 8\end{array}$ & $\begin{array}{r}119 \\
2 \cdot 5 \\
10 \cdot 9 \\
0 \\
5 \cdot 9 \\
42 \cdot 0 \\
9 \cdot 2 \\
3 \cdot 4 \\
0 \\
1 \cdot 7 \\
24 \cdot 4\end{array}$ \\
\hline
\end{tabular}


DIET AND NUTRITION

Twenty six per cent of children considered themselves overweight and had tried to lose weight. Potato crisps were the favourite snack. Fifteen per cent of children began the day with no breakfast. Sixty five per cent of children ate fruit and vegetables at least three times a week. Seventy five per cent of boys and $86 \%$ of girls considered eating less fat to be the most important dietary modification in order to be more healthy.

\section{ANTHROPOMETRY}

Height

At the age of 11 years, girls were marginally taller than boys, but boys caught up at the age of 14 years, and by the end of puberty had clearly overtaken the girls (tables 5 and 6). The height of girls levelled off at 14 years, at which time girls had in effect attained their adult height. Boys continued to increase in height up to the age of 16 , when a plateau was reached. Boys, at the completion of growth, were $12 \mathrm{~cm}$

Table 3 Cigarette consumption in children in answer to question: how many cigarettes do you normally smoke in a week? Results by age (years) as percent of total at each age

\begin{tabular}{|c|c|c|c|c|c|c|c|c|c|}
\hline & 11 & 12 & 13 & 14 & 15 & 16 & 17 & 18 & All \\
\hline $\begin{array}{l}\text { No of boys } \\
\text { No response } \\
\text { None } \\
1-5 \text { a week } \\
5-10 \text { a week } \\
10-20 \text { a week } \\
\text { Over } 20 \text { a week }\end{array}$ & $\begin{array}{r}223 \\
2 \cdot 2 \\
91 \cdot 0 \\
4 \cdot 5 \\
0 \cdot 4 \\
0 \cdot 4 \\
1 \cdot 3\end{array}$ & $\begin{array}{r}209 \\
1.9 \\
93.3 \\
2.9 \\
1.0 \\
0 \\
1.0\end{array}$ & $\begin{array}{r}211 \\
0.5 \\
91.9 \\
2.8 \\
0.9 \\
3.3 \\
0.5\end{array}$ & $\begin{array}{r}207 \\
1 \cdot 0 \\
87 \cdot 0 \\
3 \cdot 4 \\
2 \cdot 4 \\
1 \cdot 9 \\
4 \cdot 3\end{array}$ & $\begin{array}{r}215 \\
0 \cdot 5 \\
82 \cdot 3 \\
2 \cdot 3 \\
2 \cdot 3 \\
1 \cdot 4 \\
11 \cdot 2\end{array}$ & $\begin{aligned} 209 \\
1 \cdot 4 \\
78 \cdot 0 \\
4 \cdot 3 \\
1 \cdot 0 \\
3 \cdot 3 \\
12 \cdot 0\end{aligned}$ & $\begin{array}{r}181 \\
1.1 \\
81 \cdot 8 \\
2 \cdot 8 \\
2 \cdot 2 \\
2 \cdot 2 \\
9.9\end{array}$ & $\begin{array}{c}85 \\
2 \cdot 4 \\
77 \cdot 6 \\
3 \cdot 5 \\
0 \\
2 \cdot 4 \\
14 \cdot 1\end{array}$ & $\begin{aligned} 1540 \\
1 \cdot 3 \\
86 \cdot 1 \\
3 \cdot 3 \\
1 \cdot 4 \\
1 \cdot 8 \\
6 \cdot 1\end{aligned}$ \\
\hline $\begin{array}{l}\text { No of girls } \\
\text { No response } \\
\text { None } \\
1-5 \text { a week } \\
5-10 \text { a week } \\
10-20 \text { a week } \\
\text { Over } 20 \text { a week }\end{array}$ & $\begin{array}{c}223 \\
0 \cdot 9 \\
99 \cdot 1 \\
0 \\
0 \\
0 \\
0\end{array}$ & $\begin{array}{c}209 \\
2 \cdot 6 \\
94 \cdot 4 \\
3 \cdot 1 \\
0 \\
0 \\
0\end{array}$ & $\begin{array}{r}211 \\
0 \cdot 9 \\
94 \cdot 2 \\
2 \cdot 7 \\
1 \cdot 8 \\
0 \cdot 4 \\
0\end{array}$ & $\begin{array}{r}207 \\
0 \cdot 4 \\
90 \cdot 1 \\
4 \cdot 5 \\
1 \cdot 3 \\
0 \cdot 4 \\
3 \cdot 1\end{array}$ & $\begin{array}{r}215 \\
0.5 \\
81 \cdot 4 \\
5.9 \\
2.7 \\
1.8 \\
7 \cdot 7\end{array}$ & $\begin{array}{l}209 \\
0 \\
85 \cdot 0 \\
3 \cdot 1 \\
4 \cdot 4 \\
3 \cdot 5 \\
4 \cdot 0\end{array}$ & $\begin{array}{r}181 \\
0.5 \\
83.2 \\
2.5 \\
352 \\
1.5 \\
8.9\end{array}$ & $\begin{array}{l}85 \\
0 \\
72 \cdot 3 \\
4 \cdot 2 \\
8 \cdot 4 \\
2 \cdot 5 \\
12 \cdot 6\end{array}$ & $\begin{array}{r}1540 \\
0 \cdot 8 \\
88 \cdot 5 \\
3 \cdot 2 \\
2 \cdot 4 \\
1 \cdot 2 \\
3 \cdot 9\end{array}$ \\
\hline
\end{tabular}

Table 4 Alcohol consumption in children in answer to question: how often do you normally drink alcohol? Results by age (years) as percent of total at each age

\begin{tabular}{|c|c|c|c|c|c|c|c|c|c|}
\hline & 11 & 12 & 13 & 14 & 15 & 16 & 17 & 18 & All \\
\hline $\begin{array}{l}\text { No of boys } \\
\text { No response } \\
\text { I never drink alcohol } \\
\text { Less than once a week } \\
\text { Once or twice a week } \\
\text { Three to five times a week } \\
\text { Six or seven times a week }\end{array}$ & $\begin{array}{r}223 \\
0 \cdot 9 \\
88 \cdot 8 \\
5 \cdot 4 \\
3 \cdot 6 \\
0 \cdot 4 \\
0 \cdot 9\end{array}$ & $\begin{array}{r}209 \\
2 \cdot 4 \\
77 \cdot 0 \\
12 \cdot 9 \\
4 \cdot 8 \\
1 \cdot 9 \\
1 \cdot 0\end{array}$ & $\begin{array}{l}211 \\
0 \\
68 \cdot 7 \\
21 \cdot 3 \\
8 \cdot 5 \\
0 \cdot 9 \\
0 \cdot 5\end{array}$ & $\begin{array}{r}207 \\
0.5 \\
59 \cdot 9 \\
26 \cdot 6 \\
10 \cdot 6 \\
1.4 \\
1.0\end{array}$ & $\begin{array}{r}215 \\
0 \cdot 5 \\
47 \cdot 9 \\
24 \cdot 7 \\
24 \cdot 2 \\
1 \cdot 4 \\
1 \cdot 4\end{array}$ & $\begin{array}{l}209 \\
1 \cdot 0 \\
38 \cdot 3 \\
37 \cdot 3 \\
21 \cdot 1 \\
2 \cdot 4 \\
0\end{array}$ & $\begin{array}{l}181 \\
1 \cdot 1 \\
26 \cdot 0 \\
35 \cdot 4 \\
29 \cdot 3 \\
8 \cdot 3 \\
0\end{array}$ & $\begin{array}{c}85 \\
2 \cdot 4 \\
21 \cdot 2 \\
36 \cdot 5 \\
31 \cdot 8 \\
8 \cdot 2 \\
0\end{array}$ & $\begin{array}{r}1540 \\
1.0 \\
56.9 \\
23.7 \\
15.2 \\
2.6 \\
0.6\end{array}$ \\
\hline $\begin{array}{l}\text { No of girls } \\
\text { No response } \\
\text { I never drink alcohol } \\
\text { Less than once a week } \\
\text { Once or twice a week } \\
\text { Three to five times a week } \\
\text { Six or seven times a week }\end{array}$ & $\begin{array}{c}222 \\
0 \cdot 9 \\
97 \cdot 7 \\
1 \cdot 4 \\
0 \\
0 \\
0\end{array}$ & $\begin{array}{c}233 \\
1 \cdot 3 \\
90 \cdot 6 \\
6 \cdot 9 \\
1 \cdot 3 \\
0 \\
0\end{array}$ & $\begin{array}{r}225 \\
0 \cdot 4 \\
90 \cdot 7 \\
5 \cdot 8 \\
3 \cdot 1 \\
0 \\
0\end{array}$ & $\begin{array}{l}223 \\
0 \cdot 4 \\
79 \cdot 4 \\
16 \cdot 6 \\
3 \cdot 1 \\
0 \cdot 4 \\
0\end{array}$ & $\begin{array}{c}221 \\
0.5 \\
62.9 \\
25.8 \\
10.4 \\
0 \\
0.5\end{array}$ & $\begin{array}{c}226 \\
0 \\
53.5 \\
34 \cdot 1 \\
11.5 \\
0.4 \\
0.4\end{array}$ & $\begin{array}{c}202 \\
0.5 \\
42 \cdot 1 \\
34 \cdot 2 \\
22 \cdot 8 \\
0 \\
0.5\end{array}$ & $\begin{array}{c}119 \\
0 \\
31 \cdot 9 \\
40 \cdot 3 \\
26 \cdot 1 \\
1.7 \\
0\end{array}$ & $\begin{array}{r}1671 \\
0.5 \\
71.3 \\
19.2 \\
8.6 \\
0.2 \\
0.2\end{array}$ \\
\hline
\end{tabular}

Table 5 Boys' anthropometric and physical fitness characteristics by age (years). Results are mean (SD)

\begin{tabular}{|c|c|c|c|c|c|c|c|c|}
\hline & $\begin{array}{l}11 \\
(n=222)\end{array}$ & $\begin{array}{l}12 \\
(n=210)\end{array}$ & $\begin{array}{l}13 \\
(n=215)\end{array}$ & $\begin{array}{l}14 \\
(n=208)\end{array}$ & $\begin{array}{l}15 \\
(n=219)\end{array}$ & $\begin{array}{l}16 \\
(n=211)\end{array}$ & $\begin{array}{l}17 \\
(n=180)\end{array}$ & $\begin{array}{l}18 \\
(n=89)\end{array}$ \\
\hline $\begin{array}{l}\text { Height (mm) } \\
\text { Weight (kg) } \\
\text { Body mass index } \\
20 \text { metre shuttle run test (laps) } \\
\text { Sit and reach (cm) } \\
\text { Standing broad jump (cm) } \\
\text { No of sit ups completed in } 30 \text { secs } \\
\text { Grip strength (kg) } \\
10 \times 5 \text { m sprint (millisecs) }\end{array}$ & $\begin{array}{l}1449(69) \\
39 \cdot 7(7 \cdot 2) \\
17 \cdot 8(2 \cdot 4) \\
61(19) \\
16 \cdot 5(6 \cdot 0) \\
145(19) \\
22(4) \\
20(4) \\
219(19)\end{array}$ & $\begin{array}{l}1503(76) \\
42 \cdot 1(8 \cdot 8) \\
18 \cdot 5(2 \cdot 8) \\
65(17) \\
15 \cdot 0(6 \cdot 5) \\
150(20) \\
23(4) \\
23(5) \\
216(18)\end{array}$ & $\begin{array}{l}1566(82) \\
46 \cdot 5(4 \cdot 4) \\
18 \cdot 8(2 \cdot 7) \\
72(19) \\
16 \cdot 0(7 \cdot 0) \\
161(23) \\
24(4) \\
26(6) \\
208(16)\end{array}$ & $\begin{array}{l}1621(84) \\
51 \cdot 7(10 \cdot 1) \\
19 \cdot 5(2 \cdot 6) \\
79(20) \\
17 \cdot 0(6 \cdot 5) \\
169(25) \\
25(4) \\
30(7) \\
203(16)\end{array}$ & $\begin{array}{l}1689(68) \\
58 \cdot 0(9 \cdot 5) \\
20 \cdot 2(2 \cdot 7) \\
86(20) \\
19 \cdot 5(7 \cdot 5) \\
183(24) \\
25(4) \\
37(8) \\
198(15)\end{array}$ & $\begin{array}{l}1734(70) \\
64 \cdot 2(9 \cdot 6) \\
21 \cdot 3(2 \cdot 7) \\
90(18) \\
22 \cdot 0(7 \cdot 5) \\
195(24) \\
26(4) \\
42(7) \\
191(14)\end{array}$ & $\begin{array}{l}1760(67) \\
66 \cdot 5(9 \cdot 0) \\
21 \cdot 4(2 \cdot 3) \\
96(18) \\
23 \cdot 5(8 \cdot 5) \\
200(24) \\
26(4) \\
46(7) \\
189(14)\end{array}$ & $\begin{array}{l}1748(54) \\
67 \cdot 0(8 \cdot 9) \\
21 \cdot 9(2 \cdot 5) \\
98(20) \\
24 \cdot 5(7 \cdot 0) \\
205(22) \\
26(4) \\
46(7) \\
191(14)\end{array}$ \\
\hline
\end{tabular}

Table 6 Girls' anthropometric and physical fitness characteristics by age (years). Results are mean (SD)

\begin{tabular}{|c|c|c|c|c|c|c|c|c|}
\hline & $\begin{array}{l}11 \\
(n=224)\end{array}$ & $\begin{array}{l}12 \\
(n=237)\end{array}$ & $\begin{array}{l}13 \\
(n=229)\end{array}$ & $\begin{array}{l}14 \\
(n=226)\end{array}$ & $\begin{array}{l}15 \\
(n=219)\end{array}$ & $\begin{array}{l}16 \\
(n=227)\end{array}$ & $\begin{array}{l}17 \\
(n=200)\end{array}$ & $\begin{array}{l}18 \\
(n=121)\end{array}$ \\
\hline $\begin{array}{l}\text { Height }(\mathrm{mm}) \\
\text { Weight }(\mathrm{kg}) \\
\text { Body mass index } \\
20 \text { metre shuttle run test (laps) } \\
\text { Sit and reach }(\mathrm{cm}) \\
\text { Standing broad jump (cm) } \\
\text { No of sit ups completed in } 30 \text { secs } \\
\text { Grip strength }(\mathrm{kg}) \\
10 \times 5 \text { m sprint (millisecs) }\end{array}$ & $\begin{array}{c}1471(75) \\
40 \cdot 6(8 \cdot 9) \\
18 \cdot 6(2 \cdot 2) \\
41(13) \\
20 \cdot 5(6 \cdot 5) \\
131(19) \\
19(4) \\
19(4) \\
235(18)\end{array}$ & $\begin{array}{c}1511(77) \\
43 \cdot 1(8 \cdot 8) \\
18 \cdot 8(2 \cdot 8) \\
47(14) \\
20 \cdot 5(6 \cdot 0) \\
136(19) \\
20(4) \\
20(4) \\
226(20)\end{array}$ & $\begin{array}{c}1563(67) \\
48 \cdot 7(9 \cdot 3) \\
19 \cdot 8(3 \cdot 2) \\
48(15) \\
21 \cdot 5(6 \cdot 5) \\
140(21) \\
19(4) \\
23(4) \\
227(17)\end{array}$ & $\begin{array}{l}1594(60) \\
52 \cdot 9(7 \cdot 9) \\
20 \cdot 8(2 \cdot 8) \\
49(16) \\
24 \cdot 5(6 \cdot 5) \\
144(22) \\
20(4) \\
26(4) \\
224(19)\end{array}$ & $\begin{array}{l}1602(60) \\
54 \cdot 0(7 \cdot 4) \\
21 \cdot 0(2 \cdot 6) \\
49(14) \\
25 \cdot 0(6 \cdot 5) \\
145(21) \\
20(4) \\
27(4) \\
221(22)\end{array}$ & $\begin{array}{l}1620(59) \\
56 \cdot 5(7 \cdot 7) \\
21 \cdot 5(2 \cdot 7) \\
50(15) \\
25 \cdot 0(7 \cdot 0) \\
147(22) \\
20(4) \\
28(5) \\
220(19)\end{array}$ & $\begin{array}{c}1626(63) \\
56 \cdot 6(6 \cdot 9) \\
21 \cdot 4(2 \cdot 4) \\
50(16) \\
26 \cdot 0(7 \cdot 5) \\
151(22) \\
19(5) \\
29(5) \\
220(20)\end{array}$ & $\begin{array}{l}1626(56) \\
57 \cdot 2(7 \cdot 6) \\
21 \cdot 6(2 \cdot 6) \\
44(14) \\
23 \cdot 5(7 \cdot 0) \\
144(19) \\
19(5) \\
27(4) \\
232(18)\end{array}$ \\
\hline
\end{tabular}


taller than girls. The largest increase in height between successive age groups was 12-13 years for girls and 13-14 years for boys (however, boys increased in height uniformly from 11-16 years). This reflects the earlier adolescent growth spurt experienced by girls, known to occur two to three years earlier than boys.

\section{Weight}

Children's development in terms of weight closely mirrored their development in terms of height (tables 5 and 6). At 11 years, girls were 3 kg heavier than boys, but boys caught up by the age of 14 , and by the end of puberty boys were $10 \mathrm{~kg}$ heavier than girls. The largest difference in weight between consecutive age groups was 12-13 years for girls $(6.4 \mathrm{~kg})$, and 14-15 years for boys $(6.7 \mathrm{~kg})$. As with height, girls' weight levelled off at 14 years, whereas with boys, no plateau was seen until 16-17 years.

\section{Body composition}

In boys, little change was seen in the sum of four skinfold measurements during the adolescent years. However, boys experienced redistribution of fat away from the biceps and triceps towards the subscapular and suprailiac sites, that is, from the arms to the trunk. There was an increase in body mass index (weight in $\mathrm{kg} /$ height in $\mathrm{m}^{2}$ ) with age (table 7). As body mass index is normally used as a measure of fatness, this suggested that boys were increasing their fat mass. This conflict may be explained by a greater increase in both bone and muscle mass in boys, compared with height. This would cause an increase in body mass index that was not due to fat deposition.

Girls of all ages had a greater amount of adipose tissue than boys. A steady increase could be seen up to the age of 14 years, at which time a plateau was achieved. There was an appreciable increase from 13-14 years, that is, towards the end of the adolescent growth spurt.
The increase in body mass index in girls may partly reflect an increase in lean tissue, but the greatest component of the increase is likely to be the extra adipose tissue acquired by girls during puberty.

Girls showed a greater range of adiposity than boys at all ages, and both sexes showed a greater range of values before puberty than after. Boys and girls of all ages showed a greater range of results between the 50th and 80th centile than between the 20th and 50th centile, indicating that there is a greater range of 'fatter' children than 'leaner' ones.

\section{PHYSICAL FITNESS (TABLES 5 AND 6)}

Endurance running ability (20 metre shuttle run) Clear differences between the sexes could be seen in the results of the 20 metre shuttle run test. Boys outperformed girls at all ages, with a $60 \%$ difference at 11 years and a $136 \%$ difference at 18 years. Girls showed no increased ability after the age of 12 years, whereas boys showed a steady increase until the age of 17-18 years. Boys showed a larger range of scores at all ages.

The lack of improvement by girls is likely to be a consequence of increased adiposity. If this is a more significant factor than improvements in cardiovascular fitness then no improvement in endurance running ability will be seen. Boys, however, not only have the benefit of maintained or reduced fat levels, but also acquire additional aerobic capacity as a result of their increase in muscle mass.

\section{Flexibility (sit and reach)}

Both boys and girls were at their least flexible at the age of 12 years. Boys then showed a steady increase from 12-18 years with a considerable increase at $13-14$ years $(3 \mathrm{~cm})$. Girls also increased their flexibility from the age of 12 years, but the increase was not so noticeable. However, girls outperformed boys at all ages,

Table 7 Body mass index (weight in kg/height in $\mathrm{m}^{2}$ ) by age (years)

\begin{tabular}{|c|c|c|c|c|c|c|c|c|}
\hline & 11 & 12 & 13 & 14 & 15 & 16 & 17 & 18 \\
\hline $\begin{array}{l}\text { No of boys } \\
\text { Centiles }\end{array}$ & 222 & 210 & 215 & 208 & 219 & 211 & 180 & 87 \\
\hline $\begin{array}{l}90 \\
80 \\
70 \\
60 \\
50 \\
40 \\
30 \\
20 \\
10 \\
\text { Mean (SD) }\end{array}$ & $\begin{array}{l}21 \cdot 0 \\
19 \cdot 6 \\
18 \cdot 7 \\
18 \cdot 0 \\
17 \cdot 4 \\
17 \cdot 0 \\
16 \cdot 4 \\
15 \cdot 8 \\
15 \cdot 1 \\
17 \cdot 8(2 \cdot 4)\end{array}$ & $\begin{array}{l}21 \cdot 7 \\
20 \cdot 5 \\
19 \cdot 5 \\
18 \cdot 7 \\
18 \cdot 0 \\
17 \cdot 2 \\
16 \cdot 6 \\
16 \cdot 2 \\
15 \cdot 6 \\
18 \cdot 5(2 \cdot 8)\end{array}$ & $\begin{array}{l}22 \cdot 6 \\
20 \cdot 8 \\
19 \cdot 8 \\
19 \cdot 1 \\
18 \cdot 5 \\
17 \cdot 7 \\
17 \cdot 1 \\
16 \cdot 4 \\
15 \cdot 8 \\
18 \cdot 8(2 \cdot 7)\end{array}$ & $\begin{array}{l}22 \cdot 6 \\
21 \cdot 8 \\
20 \cdot 7 \\
19 \cdot 7 \\
19 \cdot 2 \\
18 \cdot 7 \\
18 \cdot 2 \\
17 \cdot 5 \\
16 \cdot 4 \\
19 \cdot 5(2 \cdot 6)\end{array}$ & $\begin{array}{l}23 \cdot 7 \\
21 \cdot 8 \\
21 \cdot 1 \\
20 \cdot 4 \\
19 \cdot 7 \\
19 \cdot 2 \\
18 \cdot 7 \\
18 \cdot 2 \\
17 \cdot 4 \\
20 \cdot 2(2 \cdot 7)\end{array}$ & $\begin{array}{l}24 \cdot 5 \\
23 \cdot 2 \\
22 \cdot 5 \\
21 \cdot 8 \\
21 \cdot 0 \\
20 \cdot 3 \\
19 \cdot 7 \\
19 \cdot 0 \\
18 \cdot 4 \\
21 \cdot 3(2 \cdot 7)\end{array}$ & $\begin{array}{l}24 \cdot 8 \\
23 \cdot 3 \\
22 \cdot 3 \\
21 \cdot 6 \\
21 \cdot 0 \\
20 \cdot 6 \\
20 \cdot 0 \\
19 \cdot 4 \\
18 \cdot 9 \\
21 \cdot 4(2 \cdot 3)\end{array}$ & $\begin{array}{l}25 \cdot 0 \\
23 \cdot 8 \\
23 \cdot 0 \\
22 \cdot 2 \\
21 \cdot 7 \\
21 \cdot 2 \\
20 \cdot 6 \\
19 \cdot 8 \\
18.7 \\
21 \cdot 9(2 \cdot 5)\end{array}$ \\
\hline $\begin{array}{l}\text { No of girls } \\
\text { Centiles }\end{array}$ & 224 & 237 & 229 & 226 & 219 & 227 & 198 & 121 \\
\hline $\begin{array}{l}90 \\
80 \\
70 \\
60 \\
50 \\
40 \\
30 \\
20 \\
10 \\
\text { Mean (SD) }\end{array}$ & $\begin{array}{l}23 \cdot 3 \\
20 \cdot 7 \\
19 \cdot 7 \\
18 \cdot 8 \\
18 \cdot 2 \\
17 \cdot 3 \\
16 \cdot 6 \\
16 \cdot 0 \\
15 \cdot 3 \\
18 \cdot 6(3 \cdot 2)\end{array}$ & $\begin{array}{l}22 \cdot 5 \\
20 \cdot 5 \\
19 \cdot 7 \\
19 \cdot 2 \\
18 \cdot 4 \\
17 \cdot 9 \\
17 \cdot 1 \\
16 \cdot 5 \\
15 \cdot 6 \\
18 \cdot 8(2 \cdot 8)\end{array}$ & $\begin{array}{l}23 \cdot 9 \\
22 \cdot 0 \\
20 \cdot 8 \\
19 \cdot 8 \\
19 \cdot 2 \\
18 \cdot 6 \\
18 \cdot 0 \\
12 \cdot 5 \\
16 \cdot 5 \\
18 \cdot 8(3 \cdot 2)\end{array}$ & $\begin{array}{l}24 \cdot 3 \\
22 \cdot 9 \\
21 \cdot 9 \\
21 \cdot 3 \\
20 \cdot 5 \\
19 \cdot 7 \\
19 \cdot 0 \\
18 \cdot 5 \\
17 \cdot 7 \\
20 \cdot 8(2 \cdot 8)\end{array}$ & $\begin{array}{l}24 \cdot 4 \\
22 \cdot 9 \\
22 \cdot 0 \\
21 \cdot 5 \\
20 \cdot 7 \\
20 \cdot 2 \\
19 \cdot 7 \\
18 \cdot 7 \\
17 \cdot 9 \\
21 \cdot 0(2 \cdot 6)\end{array}$ & $\begin{array}{l}25 \cdot 4 \\
23 \cdot 2 \\
22.5 \\
21 \cdot 8 \\
21 \cdot 1 \\
20.5 \\
19 \cdot 9 \\
19 \cdot 4 \\
18.5 \\
21.5(2 \cdot 7)\end{array}$ & $\begin{array}{l}24 \cdot 1 \\
23 \cdot 0 \\
22 \cdot 4 \\
21 \cdot 8 \\
21 \cdot 2 \\
20 \cdot 6 \\
20 \cdot 2 \\
19 \cdot 5 \\
18 \cdot 8 \\
21 \cdot 4(2 \cdot 4)\end{array}$ & $\begin{array}{l}25 \cdot 3 \\
23 \cdot 4 \\
22 \cdot 5 \\
21 \cdot 8 \\
21 \cdot 3 \\
20 \cdot 8 \\
20 \cdot 2 \\
19 \cdot 3 \\
18 \cdot 5 \\
21 \cdot 6(2 \cdot 6)\end{array}$ \\
\hline
\end{tabular}


although the gap between the sexes narrowed from the age of 14 years, until there was no apparent difference at the age of 18 years. However, this apparent equality could be a sampling artefact.

The improved flexibility with age seen in both sexes may be explained by changes in bone ratios during puberty.

Trunk strength/endurance (sit ups)

Boys outperformed girls at all ages, with boys showing a gradual increase from 11-18 years and girls showing no increase at all. This difference may be explained by the girls' increased adiposity because extra fat, especially if acquired on the upper body, will adversely affect performance.

\section{Handgrip strength (grip dynamometer)}

No sex differences in grip strength were evident between the ages of 11-13 years, with both sexes showing a gradual increase in performance. From 14 years onwards, however, boys showed an appreciable increase until the age of 17 years, whereas girls showed only a small increase. The gap between boys' and girls' performance widened continuously with age.

\section{Leg power (standing broad jump)}

No sex differences in leg power were evident between the ages of 11-13 years, with both sexes showing a gradual increase with age. From 14 years onwards, however, boys showed an appreciable increase in performance, whereas girls showed only a small increase.

Speed/agility (10 $\times 5$ metre shuttle sprint)

Boys outperformed girls at all ages. Both boys and girls showed an increase in performance from the age of 12 years, with girls showing a modest increase, whereas the boys' increase was more noticeable.

\section{GENERAL SUMMARY - ANTHROPOMETRY}

AND FITNESS

The height and weight of boys and girls increased steadily during the school age years. In boys, it seems increased weight resulted predominantly from an increase in lean tissue, whereas in girls it resulted predominantly from an increased fat mass.

The motor fitness of boys improved appreciably with age. It is likely that the principal component of the improvement was increased stature and muscle mass. The motor fitness of girls improved less dramatically and in some cases there was no improvement. Boys outperformed girls in the motor performance tests at all ages, and it is interesting to note that this was true of the prepubertal children. At this age girls were larger and may be thought to have an advantage in terms of performance. The fact that they performed worse than the boys may reflect more frequent participation in sports by boys, who therefore acquired improved coordination and neural adaptation. Alternatively, it may be that girls were less motivated to perform maximally than boys, or that the tests had a skill element, which might give boys an advantage.

Girls' performances in the endurance run and sit ups tests showed no improvement with age. The main reason for their lack of improvement, and minimal improvements in some other tests, was likely to be increased adiposity.

\section{Discussion}

Given the proposed link between physical activity and health, ${ }^{18}$ the most significant findings of this survey are the age and sex differences in physical activity levels. It appears to be the process of exercising that confers health benefits and not the ability to perform fitness tests. Although there are a significant number of very active children, especially in the younger age groups, there is also a large group of children who take part in very little physical activity. In both sexes there is an appreciable decline in physical activity after the age of 14 years and the very high percentage of inactive girls is of particular concern. There is an important interface where doctors and teachers can target these children to prevent the onset of hypokinetic disease. Because of the lack of comparative standards no claims that children are any less active than they once were can be substantiated.

In stature, body composition, and physical fitness Northern Irish children are similar to their age matched peers in other western industrialised countries: Australia, ${ }^{19} \mathrm{New}$ Zealand, ${ }^{20}$ Canada, ${ }^{21}$ and the USA. ${ }^{22}$ There is no evidence that children are any less fit now than they were in past generations. ${ }^{23}$

It is suggested that fitness in children may be largely genetically determined, ${ }^{23}$ and more evidence has been found for a decreased cardiovascular risk associated with physical activity than with physical fitness. This indicates that physical activity of a level less than that needed to improve physical fitness may confer significant health benefits. ${ }^{18}$

Physical activity may protect against heart disease by improving the lipid profile, ${ }^{15}$ maintaining blood pressure within safe limits, ${ }^{24}$ and controlling body weight. ${ }^{25}$ The protective effect of exercise, in terms of cardiovascular disease, appears to be related to the total amount of energy expended during regular physical activity rather than to the amount of vigorous exercise taken. ${ }^{26}$ Also, improvements in strength, muscle endurance, body composition, flexibility, self image, and longevity can result from levels of exercise well below those recommended for improving cardiovascular fitness. ${ }^{27}$

It has been suggested that children who engage in regular physical activity are most likely to become active adults ${ }^{2829}$ and that there is a behavioural tracking of activity levels from childhood to adulthood. ${ }^{30}$ It is therefore vital that our children are encouraged to acquire positive attitudes towards regular physical activity. 
It is encouraging that girls appear to have a reasonable knowledge of nutritional matters and that the concept of lowering fat consumption is recognised as part of a healthy diet by both boys and girls. It indicates that preventive health messages do register with children. However, it appears that the combination of energy restriction and physical exercise to bring about weight loss has not been effectively communicated to children, although this is recognised to be a more effective and permanent means to fat loss than energy restriction alone. ${ }^{31} 32$

Smoking cigarettes is clearly established as one of the major risk factors in CHD and serious respiratory disorders. ${ }^{1}$ Both this and previous studies ${ }^{33}$ suggest an incidence of between $20 \%$ and $25 \%$ in school leavers. Regular alcohol consumption in schoolchildren also has serious implications for health in adult life. Health education efforts aimed at informing children of the long term health implications of tobacco and alcohol abuse remain a priority.

\section{FUTURE RESEARCH}

Why so many children, especially girls, are inactive is one of several questions that require further study. It may be important to identify groups of children who display more than one risk factor. The clustering of risk factors is a well documented phenomenon ${ }^{34}$ and children prone to high risk might be targeted accordingly. The environmental, social, and psychological reasons that underlie such clustering needs to be identified. The final step is to develop an effective health education strategy targeted at the high risk groups. Extensive information from this baseline study is available to enable educationalists and paediatricians to press for such a preventative health programme in children. ${ }^{35}$

\section{CONCLUSION}

This survey has shown that a significant number of Northern Irish children undoubtedly display a number of adverse behavioural traits which, if continued in to adult life, may place them at considerable risk of future ill health.

Children choose their leisure pursuits, including exercise and sport, eating habits, and alcohol and tobacco use according to their perceived relative benefits and attractions. Leventhal has argued that children are no more likely to learn from or act upon health information than adults. ${ }^{36}$ Physical activity programmes will therefore only be effective if children become intrinsically motivated to exercise on their own. ${ }^{37-39}$ It is important to ensure that their experience of health education, exercise, physical education, and sport are positive to enable children to make informed choices based on knowledge and understanding. The results of this survey should be a stimulus to parents, family doctors, school medical officers, community paediatricians, educationalists, teachers, and all those who can influence the lifestyles of schoolchildren. In particular we must encourage the adoption of regular physical activity during childhood as a sound basis for acquiring a healthy adult lifestyle.

This study was jointly funded by the Department of Health and Social Services Northern Ireland (NI). The Sports Council for NI and the Department of Education for NI. We thank the children and staff of the schools from throughout Northern Ireland who took part.

1 Dawber TR. The epidemiology of atherosclerotic disease. Cambridge, Mass: Harvard University Press, 1980.

2 Register General. Northern Ireland annual report 1986. Belfast: HMSO, 1988.

3 Powell KE, Thompson PD, Casperon CJ, Kendrick KS. Ann Rev Public Health 1987;8:281-7.

4 Blair S, Kohl WK III, Paffenbarger RS Jr, Clark DG, Cooper KH, Gibbon LW. Physical fitness and all cause mortality. FAMA 1989;262:2395.

5 Ekelund L, Maskell WL, Johnson JL, Whaley FS, Criqui MH, Sheps DS. Physical fitness as a predictor of cardiovascular mortality in asymptomatic North American men. N Engl f Med 1988;319:1379.

6 Morris JN, Heady JA, Raffle PAB, Roberts CG, Parks JW. Coronary heart disease and physical activity of work. Lancet 1953;ii:1053-7.

7 Morris JN, Adam C, Chave C, Sirey C, Epstein L. Vigorous exercise in leisure time and the incidence of coronary heart disease. Lancet 1973;i:333-9.

8 Paffenbarger RS, Hale WE, Brand RJ, Hyde RT. Workenergy level, personal characteristics and fatal heart attack: a birth-cohort effect. Am F Epidemiol 1977;105:200-13.

9 Paffenbarger RS, Wing AL, Hyde RT'. Physical activity as an index of heart attack risk in college alumni. Am $\mathcal{f}$ Epidemiol 1978;108:161-75.

10 Berenson GS, McMahan CA, Voors AW, Webber LS. Cardiovascular risk factors in children. The Bogalusa heart study. Oxford: Oxford University Press, 1980.

11 Gilliam TB, Katch VL, Thorland WG, Weltman AW. Prevalence of coronary heart disease risk factors in active Prevalence of coronary heart disease risk factors in active
children 7 to 12 years of age. Med Sci Sports Exerc children 7 1977;9:21-5.

12 Lauer RM, Connor WE, Leaverton PE, Reiter MA, Clarke WR. Coronary heart disease risk factors in school children: the Muscatine study. $\mathcal{F}$ Pediatr 1975;86:697-706.

13 Morrison JA, Horvitz R, Khoury P, Laskarzewsa P, Gartside PS. Parental history of coronary heart disease risk factor variables in their adult children. Prev Med 1980;9:773-86.

14 Newman WP, Freedman DS, Voors AW. Relation of serum lipoprotein levels and systolic blood pressure to early atherosclerosis. The Bogalusa heart study. $N$ Engl $\mathcal{Y} M e d$ 1986;314:138-44.

15 Goldberg L, Elliott DL. The effect of physical activity on lipid and lipoprotein levels. Med Clin North Am 1985;69: 41-5.

16 Council of Europe. Eurofit handbook for the Eurofit tests of physical fitness. Rome: Committee for the Development of Sport, 1988.

17 Boreham CAG, Paliczka VJ, Nichols AK. A comparison of the $P_{W C} C_{170}$ and 20-MST tests of aerobic fitness in adolescent schoolchildren. I Sports Med Phys Fitness 1990;30:19-23.

18 Blair SN, Jacobs DR, Powell KE. Relationships between exercise or physical activity and other health behaviours. Public Health Rep 1985;100:172-80.

9 Australian Council for Health, Physical Education and Recreation. Australian health and fitness survey. Parkside, South Australia: ACHPER, 1985

20 University of Otago. The New Zealand fitness test handbook. Otago: University of Otago, New Zealand, 1988.

21 Shepherd RJ. The Canada fitness survey. Some international comparisons. F Sports Med Phys Fitness 1986;26:292-300.

22 National Technical Information Service. National youth fitness study. Springfield: NTIS, 1985.

23 Klissouras V, Pernay F, Petit M. Adaptations to maximal effort: genetics and age. 7 Appl Physiol 1973;35:288-93.

24 Fagard R. Habitual physical activity, training, and blood pressure in normo- and hypertension. Int $\mathcal{f}$ Sports Med 1985;6:57-67.

25 American College of Sports Medicine. Position statement on proper and improper weight loss programmes. Med Sci Sports Exerc 1983;15:9.

26 Paffenbarger RS, Hyde RT, Wing AL, Hsieh C. Physical activity, all-cause mortality, and longevity of college alumni. N Engl f Med 1986;314:605-13.

27 American College of Sports Medicine. The recommended quantity and quality of exercise for developing and maintaining cardiorespiratory and muscular fitness in adults. Med Sci Sports Exerc 1990;22:265-74.

28 Pate RR, Blair SN. Exercise and the prevention of atherosclerosis: pediatric implications. In: Strong WB ed. Atherosclerosis: its pediatric aspects. New York: Grune Stratton, 1978: 251-86.

29 Saris WHM. The assessment and evaluation of daily physical activity in children. A review. Acta Paediatr Scand Suppl 1985;318:37-48.

30 Simons-Morten BG, O'Hara NM, Simons-Morton OG, Pariel GS. Children and fitness: a public health perspective. Research Quarterly for Exercise and Sport 1987;58:295-302. 
31 McArdle WD, Magel JR. Weight measurement: diet and exercise. In: Bland J, Shealy N, eds. The medical aspects of clinical nutrition. New Canaan, CT: Keats, 1983.

32 Colvin RH, Olson SB. A descriptive analysis of men and women who have lost significant weight and are highly successful at maintaining the loss. Addict Behav 1983;8: 287.

33 Goddard E. Smoking among secondary school children in England in 1988. London: HMSO, 1989.

34 Webber LS, Freedman DS. Interrelationships of coronary heart disease risk factors in children. In: Berenson GS, ed. Causation of cardiovascular risk factors in children. New York: Raven Press, 1986

35 Riddoch C. Report of the Northern Ireland health and fitness survey. Belfast: Department of Physical and Health Education, Queen's University of Belfast, 1990.

36 Leventhal $H$. Changing attitudes and habits to reduce risk factors in chronic disease. Am $\mathcal{F}$ Cardiol 1973;31:571-80.

37 Corbin CB. Youth fitness exercise and health. There is much to be done. Research Quarterly for Exercise and Sport 1987;58:308-14.

38 Fox KR, Biddle STH. The use of fitness tests educational and physical considerations. Fournal of Physical Education, and physical considerations. Fournal of $P$

39 Gilbert R, van Wersch A. Motivating children to participate in sport. In: Kolmer J, Crawford W, eds. The psychology of sport theory and practice. Leicester: The British Psychological sport theory and practice.
Society, 1989:60-6.

\section{Crying babies of the Kalahari}

Dr Ronald Barr of Montreal Children's Hospital has contributed much to our knowledge of crying in babies and 'infant colic' (see Archivist 1991:970). In an annotation in Developmental Medicine and Child Neurology in April 1990 he summarised what is known about normal crying behaviour. ${ }^{1}$ Many studies have shown that fussing and crying (and the two may be biologically different) rise to a peak at around 6 weeks of age then decline to a fairly constant level between 3 and 12 months. There is a diurnal variation with crying clustering in the late afternoon and evening and this too is most marked at around 6 weeks. Although this feature remains fairly constant in different populations of babies, there is considerable interinfant and intrainfant variability. This pattern is true of the duration of crying during the 24 hours but the frequency of crying episodes tends not to show such a strict age relationship. The pattern has been thought to be an innate biological feature of the species unrelated to caretaking practices but Hunziker and Barr in 1986 showed that increased carrying of babies reduced the amount of crying and eliminated the early peak. ${ }^{2}$ So is the pattern of crying observed in babies in technologically advanced societies a feature of such societies or a species specific biological characteristic?

The !Kung San people are hunter-gatherers who live in the Kalahari desert in north west Botswana and who were 'anthropologised' in the 1970s. Now Dr Barr has joined forces with an anthropologist, Dr Konner, and two psychologists, Drs Bakeman and Adamson, to publish data gathered in Botswana between 1969 and 1971 and in 1975 (Developmental Medicine and Child Neurology 1991;33:601-10). !Kung San mothers are supremely responsive to their babies. They hold or carry them for over $80 \%$ of the day time and respond immediately to their fussing or crying (over $\mathbf{9 2 \%}$ response within 15 seconds). The data show that !Kung San babies also have a peak of crying in the first three months and that there is little difference in the frequency of crying between them and Dutch or American babies but their total duration of crying during the day is about half that of Dutch babies. In 'Western' infants $40 \%$ of crying in early infancy occurs between $6.00 \mathrm{pm}$ and midnight. The !Kung San data do not provide information about diurnal variation and it is possible that these babies make up for their relative quietness during the times they were observed by crying at other times during the day or at night.

Present information, therefore, suggests that a peak in duration of crying in the second or third month is characteristic of the human species. Changes in caretaking practices alter the duration but not the frequency of crying. It is suggested that early crying is a reflection of physiological state ('expressive' crying) but later crying is more controlled and response determined ('communicative' crying). Fairly frequent, brief fretting as seen in the !Kung San is probably biologically valuable because it induces positive responses in the caregiver, but prolonged crying as is seen more often in 'Western' babies may provoke negative responses. It is tempting to relate this to non-accidental injury.

\section{ARCHIVIST}

1 Barr RG. The normal crying curve: what do we really know? Dev Med Child Neurol $1990 ; 32: 356-62$

2 Hunziker UA, Barr RG. Increased carrying reduces infant crying: a randomized controlled trial. Pediatrics 1986;77:641-8. 